\title{
JABON (Anthocephalus cadamba Roxb) POTENCY FOR REMEDIATING LEAD (Pb) TOXICITY UNDER NUTRIENT CULTURE CONDITION
}

\author{
LULUK SETYANINGSIH ${ }^{1 *}$, YADI SETIADI ${ }^{2}$, SRI WILARSO BUDI ${ }^{2}$, HAMIM $^{3}$ \\ and DIDY SOPANDIE \\ 'Department of Forestry, Universitas Nusa Bangsa, Bogor 16166, Indonesia \\ ${ }^{2}$ Department of Silviculture, Faculty of Forestry, Institut Pertanian Bogor, Bogor 16680, Indonesia \\ ${ }^{3}$ Department of Biology, Faculty of Mathematics and Natural Sciences, Institut Pertanian Bogor, Bogor 16680, Indonesia \\ ${ }^{4}$ Department of Agronomy, Faculty of Agriculture, Institut Pertanian Bogor, Bogor 16680, Indonesia
}

Received 25 October 2016/Accepted 18 September 2017

\begin{abstract}
Information on metal adaptation of plants is necessary to understand the mechanism of heavy metal, including lead $(\mathrm{Pb})$, remediation mediated by forest plants in contaminated land. This study aimed to find out the adaptation mechanism of jabon (Anthocephalus cadamba Roxb) seedlings to excessive lead level based on the tolerance index of growth performance and lead transport to plant tissue. The seedlings were exposed to lead $\left(\mathrm{Pb}\left(\mathrm{NO}_{3}\right)_{2}\right)$ with the concentrations of $0,0.5,1,1.5,5$ and $10 \mathrm{mM}$ in nutrient culture for 15 days. The result showed that the tolerance index (TI) of the seedlings was significantly decreased by $\mathrm{Pb}$ exposure up to $1.5 \mathrm{mM}$, but the TI values were more than $75 \%$. All seedlings died at $\mathrm{Pb}$ concentration of $5 \mathrm{mM}$ and up. $\mathrm{Pb}$ accumulated in all parts of the seedlings, with the highest concentration found in the leaves $(735.9 \mathrm{ppm})$ under $\mathrm{Pb}$ concentration of $0.5 \mathrm{mM}$. The $\mathrm{Pb}$ was found to be transported to the top portion of the seedlings indicated by Transport Factor (TF) that was more than 1 . The results suggest that jabon can adapt to excessive $\mathrm{Pb}$ exposure up to $1.5 \mathrm{mM}$ and has the potential as a remediator plant.
\end{abstract}

Keywords: accumulation, jabon, lead, nutrient culture, tolerance

\section{INTRODUCTION}

Lead $(\mathrm{Pb})$ is considered as the second most dangerous heavy metal after arsenic and it is among the biggest pollutants in water and terrestrial ecosystems generated from a variety of activities including household and industrial works (Ebrahimpour \& Mushrifah 2008; Tangahu et al. 2011; Alaribe \& Agamuthu 2015). In a certain concentration, $\mathrm{Pb}$ is toxic to plants, animals, and microorganisms. When absorbed by the human body, it will produce various deleterious effects on the hematopoietic, renal, reproductive and central nervous system, mainly through increased oxidative stress (Flora et al. 2012).

Heavy metal contamination in the soil can reduce soil fertility for long-term. High Pb levels in

\footnotetext{
*Corresponding author: luluk.setya@gmail.com
}

the soil need remedial action to enable the soil to regain its normal function (Tangahu et al. 2011). Phytoremediation has become an effective, environmentally friendly and affordable technological solution through the extraction or removal of inactive metals and metal pollutants from contaminated soil (Henry et al. 2013; Sharma \& Pandey 2014). Phytoremediation is based on the fact that plants have membrane active pumps that work through solar energy to extract certain heavy metals from the environment to proceed with the translocation, bioaccumulation, or contaminant degradation depending on the abilities of the entire plant body (Rascioa \& Navari-Izzo. 2011; Tangahu et al.2011).

Jabon (Anthocephalus cadamba) is known as a tropical forest species with high tolerance to marginal land, and high shoot and roots biomass productions (Krisnawati et al. 2011; Setyaningsih et al. 2012). Forest plants with deep roots 
character and great biomass have a great potential to be used as remediator plant (Capuana 2010) in contaminated forest land. However, there is still limited information about the tolerance character of tropical forest plants to heavy metals and their potentcy as remediators. Each plant may have a tolerant level and pattern of different adaptations to heavy metal exposure conditions. There is still little information related to tolerant level of Jabon to lead, even though many other species have been extensively evaluated such as sunflower (Niu $e t a l$. 2010; Kim et al. 2009), canola, mustard and vetiver grass (Kim et al. 2009), Lantana camara (Alaribe \& Agamuthu 2015) and Pinus radiata (Javris \& Leung 2002). Therefore, the effort to learn about the tolerance and remediation capability of Jabon to heavy metal $\mathrm{Pb}$ is necessary and important.

This research was conducted in nutrient culture media to determine (1) the tolerant level of Jabon seedlings to $\mathrm{Pb}$ by observing root growth and biomass, and (2) the degree by which Jabon seedlings absorb $\mathrm{Pb}$.

\section{MATERIALS AND METHODS}

Ninety Jabon seedlings aged one month old with $5 \mathrm{~cm}$ height were obtained from the Tissue Culture Laboratory of the SEAMEO Regional Centre for Tropical Biology (BIOTROP) in Bogor, Indonesia, and transferred into culture media in plastic box containers equipped with aerator tubes for lead exposure experiment. These seedlings were grown in aerator tubes containing 1 litre of liquid nutrient culture media (Sopandie 1990) adapted for 4 days and then subjected to a treatment media using $\mathrm{Pb}$ for 15 days. Adaptation nutrient was $1 / 5$ dosage of nutrient culture without $\mathrm{Pb}$. Media treatment was $1 / 3$ dosage of nutrient culture treated by $\mathrm{Pb}(\mathrm{NO} 3)_{2}$ with 6 different $\mathrm{Pb}$ concentrations i.e. $0,0.5,1,1.5,5$ and $10 \mathrm{mM}$, respectively (Setyaningsih et al. 2012). During the experiment, the media culture was set to have $\mathrm{pH}$ 4.5-5 using $\mathrm{NaOH}$ and $\mathrm{HCl}$. Composition of nutrient culture refers to the "Sopandie Nutrient Solution" (Sopandie 1990) consisting of distilled water and nutrient solution which contained $1.5 \mathrm{mM} \mathrm{Ca}\left(\mathrm{NO}_{3}\right)_{2} 4 \mathrm{H}_{2} \mathrm{O} ; 1.0 \mathrm{mM}$ $\mathrm{NH}_{4} \mathrm{NO}_{3} ; 1.0 \mathrm{mM} \mathrm{KCl} ; 0.4 \mathrm{mM} \mathrm{MgSO} ; 1.0 \mathrm{mM}$ $\mathrm{KH}_{2} \mathrm{PO}_{4} ; 0.50$ ppm $\mathrm{MnSO}_{4} ; 0.02 \mathrm{ppm}$ $\mathrm{CuSO}_{4} .5 \mathrm{H}_{2} \mathrm{O} ; 0.05 \mathrm{ppm} \mathrm{ZnSO}_{4} \cdot 7 \mathrm{H}_{2} \mathrm{O} ; 0.05 \mathrm{ppm}$ $\mathrm{H}_{3} \mathrm{BO}_{3} ; 0.01 \mathrm{ppm}\left(\mathrm{NH}_{4}\right)_{6} \mathrm{Mo}_{7} \mathrm{O}_{24} \cdot 4 \mathrm{H}_{2} \mathrm{O} ; 68 \mathrm{mM}$
FeEDTA. During the adaptation and treatment, the aeration was supplied using electrical aerator.

Parameters analysed in the experiment were root and shoot growth and plant biomass to verify the response of plants to all $\mathrm{Pb}$ treatments. $\mathrm{Pb}$ content was analyzed only from samples of control plants (without $\mathrm{Pb}$ ), the plants with lowest $\mathrm{Pb}$ treatment $(0.5 \mathrm{mM})$, and the plant with highest $\mathrm{Pb}$ treatment by which the plants were still alive until the end period of the treatment, to compare the accumulation capacity of plants under lower and higher $\mathrm{Pb}$ concentration in the media.

Seedling growth was observed by measuring the length of roots and stems, and dry biomass weight when the plant samples were harvested. The number of dead seedlings was also counted. The tolerance index (TI) was calculated at different $\mathrm{Pb}$ concentrations using the following equation: TI $(\%)=100 \mathrm{x}$ (root length under metal treatment)/(root length in the control solution) (Wang et al. 2011). If TI $<50=$ Not tolerant; $50 \leq \mathrm{TI}<100=$ Medium tolerant; TI $\geq 100=$ Tolerant (professional judgment).

$\mathrm{Pb}$ accumulation in seedling tissue was calculated by measuring the concentration of $\mathrm{Pb}$ in the roots, stems and leaves of control plants, the plants with lowest $\mathrm{Pb}$ treatment $(0.5 \mathrm{mM})$, and the highest treatment that were still alive. The seedlings were harvested and dried in the oven with a temperature of $45 \pm 2{ }^{\circ} \mathrm{C}$ until its weight was constant. Special preparation for seedling roots, before being dried, considted of soaking them in $1.0 \mathrm{mM}$ H-EDTA for 30 minutes to remove $\mathrm{Pb}$ attached on the root surface and rinsed three times in $\mathrm{H}_{2} \mathrm{O}$ (Javris \& Leung 2002). $\mathrm{Pb}$ concentration was determined using Atomic Absorption Spectroscopy (AAS) which previously had been calibrated with a standard solution of $\mathrm{Pb}$. The obtained $\mathrm{Pb}$ concentration was then used for calculating the value of Bioconcentration Factor (BCF), Transport Factor (TF) and Bioaccumulation (B) (Mun et al. 2008), using the following the equations:

$$
\begin{aligned}
& \mathrm{BCF}= \mathrm{C}_{\text {root }} / \mathrm{C}_{\text {soil }} \\
& \text { where } \mathrm{C}_{\text {root }} \text { is the concentration of } \mathrm{Pb} \text { in } \\
& \text { roots and } \mathrm{C}_{\text {soil }} \text { is } \mathrm{Pb} \text { concentration in soil } \\
& / \text { media } \\
& \mathrm{TF}= \mathrm{C}_{\text {aerial }} / \mathrm{C}_{\text {root }} \\
& \text { where } \mathrm{C}_{\text {aerial }} \text { is } \mathrm{Pb} \text { concentration in the } \\
& \text { shoots } \\
& \mathrm{B}= \mathrm{C}_{\text {aerial }} \times \mathrm{DW} \text { ( } \mathrm{g} \mathrm{Pb} / \text { plant) where } \mathrm{DW} \text { is } \\
& \text { tissue dry weight }
\end{aligned}
$$


The study was carried out in completely randomized design for 6 treatments of different $\mathrm{Pb}$ concentrations, i.e. $\mathrm{P} 0=$ without $\mathrm{Pb}(0 \mathrm{mM})$, $\mathrm{P} 1=0.5 \mathrm{mM}$ of $\mathrm{Pb}, \mathrm{P} 2=1.0 \mathrm{mM}$ of $\mathrm{Pb}, \mathrm{P} 3=1.5$ $\mathrm{mM}$ of $\mathrm{Pb}, \mathrm{P} 4=5 \mathrm{mM}$ of $\mathrm{Pb}$ and $\mathrm{P} 5=10 \mathrm{mM}$ of $\mathrm{Pb}$. Each treatment was repeated 3 times. Three plants were used per unit of treatment, so that the total plants were 54 plants. All the data were analysed using the Microsoft Excel and SPSS 16 to calculate the analysis of variance and to compare the means of the treatments by DMRT analysis. The analysis of regression was also carried out to recognize the typical pattern of the treatment effects (exposure of $\mathrm{Pb}$ ).

\section{RESULTS AND DISCUSSION}

\section{$\mathrm{Pb}$ Tolerance of Jabon Seedling}

All Jabon seedlings exposed to $\mathrm{Pb}$ up to 1.5 $\mathrm{mM}$ were able to survive until 15 days. However, seedlings exposed to $\mathrm{Pb}$ of $5 \mathrm{mM}$ and $10 \mathrm{mM}$ showed toxicity symptoms during the second day and completely died after 5 days suggesting that 5 $\mathrm{mM}$ is a toxic concentration for Jabon seedling. This supports the findings of Hadi and Aziz (2015) and Wang et al. (2011). The symptom started with chlorosis and necrosis on the tip of the leaves (the leaves turned to yellow and dried up) on the $2^{\text {nd }}$ day, followed by the appearance of brown spots on the $3^{\text {rd }}$ day. On the $4^{\text {th }}$ day, most of the leaves rolled up and finally dried on $5^{\text {th }}$ day followed by drying of the petiole and branch in the following days. Toxic symptoms also appeared in the roots of the seedlings. By this reason, the measurement of $\mathrm{Pb}$ concentration of the highest treatment was carried out from the plants treated by $1.5 \mathrm{mM}$ of $\mathrm{Pb}$. The seedlings grown in the media without $\mathrm{Pb}$ had fibrous root with white and transparent colour. The seedlings exposed to 0.5 $1.5 \mathrm{mM}$ of $\mathrm{Pb}$ had white fibrous roots with some dark gray spost (about $1 \mathrm{~cm}$ ) while the whole roots of seedlings exposed to 5 and $10 \mathrm{mM}$ of $\mathrm{Pb}$ had became dark indicating cell death.

Symptoms of toxicity due to $\mathrm{Pb}$ began with yellowing leaves, the appearance of brown spots in almost all the leaves, leaf curling and leaf drying as well as stem drying on following days with a grayish black color of roots. These symptoms had also been reported in other plants such as Chlorophytum comosum (Wang et al. 2011), Vigna unguiculata (Kopitte et al. 2007) and Paraserianthes falcataria (Setyaningsih et al. 2012). Chlorosis and necrosis occurred presumably because photosynthetic pigment was damage as a result of decreased production of chlorophyll $\mathrm{a}$ and $\mathrm{b}$ when $\mathrm{Pb}$ exposure increased up to $1500 \mathrm{ppm}$ (Wang et al. 2011). The declined production of chlorophyll occurred as a result of heavy metal disturbance that replaced magnesium $(\mathrm{Mg})$, an important ion in the central of chlorophyll molecules, and inhibit the synthesis of chlorophyll by inhibition of enzyme activity (Wang et al. 2011; Xiao et al. 2008).

Root damage was very likely caused by the rapid inhibition of root growth. Inhibition of root growth could be caused by inhibition of cell division in root tip due to immobilization of $\mathrm{Pb}$ ion in the cell wall (Jiang \& Liu 2010). Roots became blackish, short and fat. This phenomenon has also been reported on the roots of $V$. unguiculata which became shorter and had more secondary roots (Hadi \& Aziz 2015), and also on the roots of $P$. falcataria in response to $\mathrm{Pb}$ exposure (Setyaningsih et al.2012).

$\mathrm{Pb}$ treatment for 15 days caused significant decrease $(p<0.05)$ in root length, dry weight and tolerance index (TI) of Jabon seedlings. Root length value ranged from 8.3 to $11 \mathrm{~cm}$ which gradually decreased by increasing $\mathrm{Pb}$ concentration exposure (Table 1). Dry weight of seedlings had value range of $1.28-1.63 \mathrm{~g}$ which decreased following the pattern of open polynomial curve of $y=0.48 x^{2}-0.94 x+1.63\left(R^{2}\right.$ $=1, \mathrm{p}<0.05)$. The TI of Jabon seedlings ranged from $75 \%$ to $100 \%$ which decreased significantly with the increase in $\mathrm{Pb}$ concentration exposure, and the maximum reduction was 25\% (Table 1).

There was no significant change on the growth performance of Jabon seedlings when exposed to $\mathrm{Pb}$ concentration up to $1.5 \mathrm{mM}$, with TI value of $75 \%$ or higher. This data showed that Jabon seedlings can be categorized as having intermediate tolerance to $\mathrm{Pb}$. The TI value of Jabon seedling to $\mathrm{Pb}$ is apparently smaller than $P$. falcataria seedling with TI value of $90 \%$ when exposed to the same level of $\mathrm{Pb}$ (Setyaningsih et al. 2012), and also smaller than Chlorophytum comosum with TI value of $73 \%$ even though it was exposed to $1500 \mathrm{mg} \mathrm{kg}^{-1}$ (1500 ppm) of $\mathrm{Pb}$ for 90 days (Wang et al. 2011). Moreover, the TI of Jabon was also even smaller compared to Acacia farnesiana, known as $\mathrm{Pb}$ bioaccumulator, which 
Table 1 Growth of jabon seedling exposured to $\mathrm{Pb}$ on nutrient culture during 15 days

\begin{tabular}{cccc}
\hline $\mathbf{P b}(\mathbf{m M})$ & Root Length $(\mathbf{c m})$ & Dry Biomass (gram) & TI $(\mathbf{\%})$ \\
\hline $\mathrm{Pb} \mathrm{0}$ & $11.0 \pm 1.0 \mathrm{~b}^{*}$ & $1.63 \pm 0.34 \mathrm{~b}$ & $100 \mathrm{bc}$ \\
$\mathrm{Pb} \mathrm{0.5}$ & $8.8 \pm 0.2 \mathrm{a}$ & $1.28 \pm 0.14 \mathrm{a}$ & $80 \mathrm{ab}$ \\
$\mathrm{Pb} \mathrm{1}$ & $8.3 \pm 0.6 \mathrm{a}$ & $1.38 \pm 0.33 \mathrm{a}$ & $75 \mathrm{a}$ \\
$\mathrm{Pb} \mathrm{1.5}$ & $8.5 \pm 0.5 \mathrm{a}$ & $1.30 \pm 0.13 \mathrm{a}$ & $77 \mathrm{ab}$ \\
\hline
\end{tabular}

Note: ${ }^{*}$ mean \pm standard deviation followed by the same letter in the same column indicates no significant difference in the error rate of $5 \%$ by DMRT test

the TI decreased only $8 \%$ when exposure to 1000 $\mathrm{mg} \mathrm{l}^{-1} \mathrm{~Pb}$ for 60 days (Amalia et al. 2011). The TI level of Jabon to $\mathrm{Pb}$ is better than cuttings of Jatropha curcas which has a TI value less than $80 \%$ when exposed to $0.5 \mathrm{mM}$ of $\mathrm{Pb}$ and became only $39.2 \%$ when it was exposed to $4 \mathrm{mM} \mathrm{Pb}$ (Shu et al. 2011), or even lower if it was compared to the growth of annual plant such as cowpea (Vigna unguiculata) which was recorded to be hampered by only being exposed to $1 \mu \mathrm{M}$ of $\mathrm{Pb}$ (Kopitte et al. 2007).

\section{$\mathrm{Pb}$ Concentration, Distribution and Bio- accumulation in Jabon Seedlings}

Exposure of Jabon seeldings to $\mathrm{Pb}$ for 15 days in liquid culture caused an increase of $\mathrm{Pb}$ concentration in seedling tissue up to $735 \mathrm{ppm}$ or approximately 12.6 times higher in seedlings under control treatment. The largest average of $\mathrm{Pb}$ concentration was found in the leaves $(735.93$ $\mathrm{ppm})$, then in the roots (459.04 ppm) and the in the stems (438.96 ppm) (Table 2). The pattern of $\mathrm{Pb}$ concentration in response to the increasing $\mathrm{Pb}$ exposure followed the trend of open downward polynomial curve of $y=-626.79 x 2+1077.9 x+$ $76.81\left(\mathrm{R}^{2}=1, \mathrm{p}<0.05\right)$ (Figure 1).

Comparison of $\mathrm{Pb}$ concentration in seedling tissues to that in media indicates the value of
Bioconcentration Factor (BCF). BCF value of Jabon seedlings was found to range from 0.5 to 2.9, and the biggest average of BCF was found in the leaves $(0.6$ - 4.6). The BCF value of Jabon seedlings exposed to $0.5 \mathrm{mM}$ of $\mathrm{Pb}$ was the highest as compared to that of Jabon exposed to $1.5 \mathrm{mM}$ of $\mathrm{Pb}$ or lower concentration (Figure 2).

Comparison of $\mathrm{Pb}$ content in the stems and leaf tissues to that of the root seedlings indicates the value of the transport factor (TF). The TF value of $\mathrm{Pb}$ in Jabon seedlings was found to range from 0.4 to 1.63 . The TF value of leaves was greater than that of stem. The TF value increased by $\mathrm{Pb}$ exposure to 0.5 and $1.5 \mathrm{mM}$, with the highest TF value observed in seedlings exposed to $0.5 \mathrm{mM}$ of $\mathrm{Pb}$ (Figure 3).

$\mathrm{Pb}$ bioaccumulation in Jabon seedlings was observed to range from 1.73 to $36.55 \times 10^{-2}$ $\mathrm{mg} /$ plant. The highest $\mathrm{Pb}$ accumulation was recorded in roots at 3.74 to $36.55 \times 10^{-2} \mathrm{mg} / \mathrm{plant}$. The seedlings exposed to $0.5 \mathrm{mM}$ of $\mathrm{Pb}$ had the highest bioaccumulation value ranging from 10.41 to $36.55 \times 10^{-2} \mathrm{mg} /$ plants, followed by the seedlings exposed $1.5 \mathrm{mM}$ of $\mathrm{Pb}$ (Table 3). The highest value of bioaccumulation occurred in the roots treated by $0.5 \mathrm{mM}$ of $\mathrm{Pb}$ that was almost 10 times higher than that of the control, i.e. $36.55 \mathrm{x}$ $10^{-2} \mathrm{mg} /$ plant (Table 3).

Table $2 \mathrm{~Pb}$ concentrations on parts of jabon seedlings after 15-days exposure in nutrient culture

\begin{tabular}{cccc}
\hline \multirow{2}{*}{ Pb Exposure $(\mathbf{m M})$} & \multicolumn{3}{c}{ Pb Concentration per g dry weight (ppm) } \\
\cline { 2 - 3 } & Roots & Stem & Leaves \\
\hline $\mathrm{Pb} 0$ & $76.81 \pm 18.60 \mathrm{~b}^{*}$ & $27.61 \pm 15.98 \mathrm{a}$ & $58.38 \pm 34.97 \mathrm{a}$ \\
$\mathrm{Pb} 0.5$ & $459.04 \pm 94.76 \mathrm{~d}$ & $438.96 \pm 206.63 \mathrm{c}$ & $735.93 \pm 205.78 \mathrm{~d}$ \\
$\mathrm{~Pb} 1.5$ & $283.32 \pm 1.06 \mathrm{c}$ & $164.34 \pm 24.44 \mathrm{ab}$ & $360.06 \pm 56.35 \mathrm{c}$ \\
\hline
\end{tabular}

Note: "mean \pm standard deviation followed by the same letter in the same column indicates no significant difference in the error rate of $5 \%$ by DMRT test 


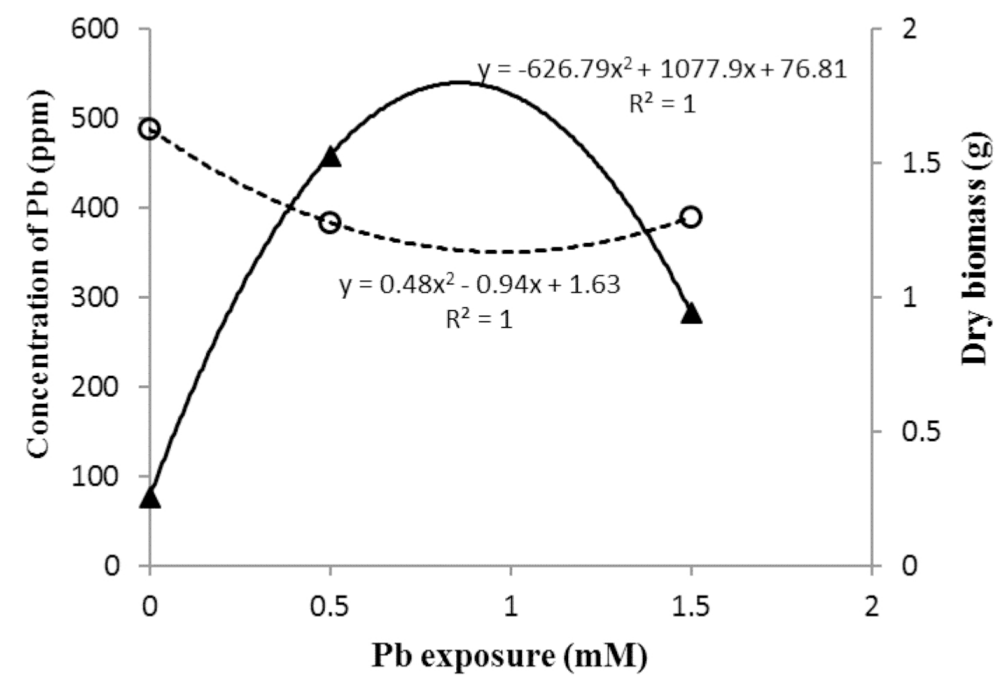

Figure 1 Relation of $\mathrm{Pb}$ concentration $(\mathbf{\Delta})$ in root and dry biomass (o) of jabon seedling on $\mathrm{Pb}$ exposure

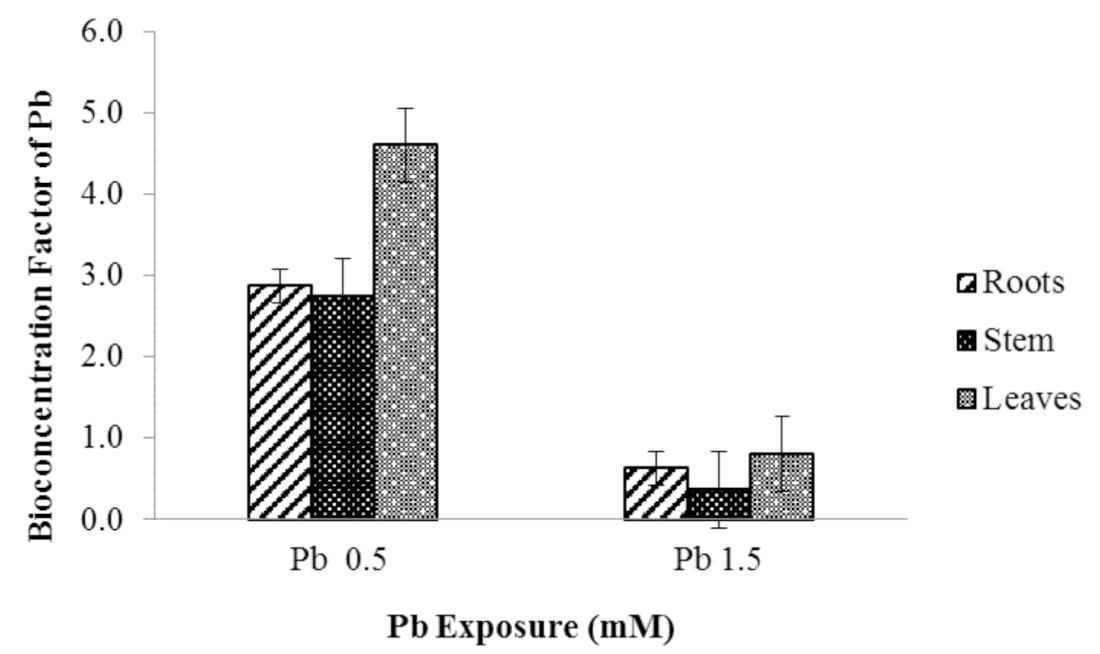

Figure 2 Bioconcentration Factor of Pb on roots, stem and leaves of Jabon seedlings exposed to Pb during 15 days (Note: The dashed line showed the threshold of plant categorized as Pb extractor (Tangahu et al.2011))

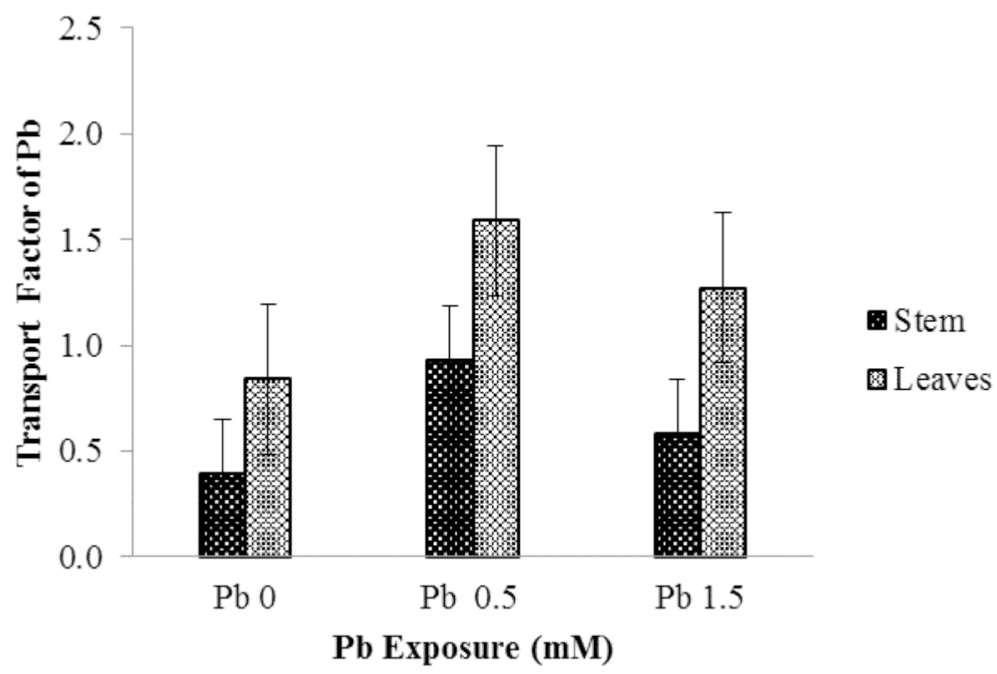

Figure 3 Transport Factor of $\mathrm{Pb}$ on stems, and leaves of Jabon seedlings exposed to $\mathrm{Pb}$ during 15 days 
Table $3 \mathrm{~Pb}$ bioaccumulation in jabon seedlings exposed to $\mathrm{Pb}$ during 15 days in nutrient culture

\begin{tabular}{cccc}
\hline \multirow{2}{*}{$\mathbf{P b}(\mathbf{m M})$} & \multicolumn{3}{c}{ Bioaccumulation (10-2 $\mathbf{m g} /$ plant $)$} \\
\cline { 2 - 4 } & Roots & Stem & Leaves \\
\hline $\mathrm{Pb} \mathrm{0}$ & $3.74 \pm 1.06 \mathrm{a}^{*}$ & $2.82 \pm 0.11 \mathrm{a}$ & $1.73 \pm 0.56 \mathrm{a}$ \\
$\mathrm{Pb} \mathrm{0.5}$ & $36.55 \pm 8.90 \mathrm{c}$ & $10.41 \pm 1.15 \mathrm{c}$ & $24.58 \pm 0.76 \mathrm{c}$ \\
$\mathrm{Pb} 1.5$ & $18.12 \pm 1.98 \mathrm{~b}$ & $7.18 \pm 1.27 \mathrm{~b}$ & $8.98 \pm 0.82 \mathrm{~b}$ \\
\hline
\end{tabular}

Note: ${ }^{*}$ mean \pm standard deviation followed by the same letter in the same column indicates no significant difference in the error rate of $5 \%$ by DMRT test

Jabon seedlings exposed to $\mathrm{Pb}$ for 15 days in a nutrient culture led to an increase of $\mathrm{Pb}$ concentration in the seedling tissues. Based on BCF value which ranged between 0.4 and 4.6, the $\mathrm{Pb}$ exposure in the media culture led to the increase of $\mathrm{Pb}$ concentration in the tissues of the seedlings with the highest concentration recorded at $735 \mathrm{ppm}$ or 12.6 times higher than that of the control (Table 2). The leaves of the seedlings exposed to $0.5 \mathrm{mM}$ of $\mathrm{Pb}$ were found to have the largest $\mathrm{Pb}$ concentration followed by the roots and then stems, with the TF values was ranging from 0.9 to 1.59 (Table 2, Fig. 1 and 2). This result showed that $\mathrm{Pb}$ concentration in Jabon seedlings was greater as compared to that of Pinus radiata (390 ppm) (Javris \& Leung 2002), but lower than that in kenaf (4281 ppm) (Mun etal. 2008), P. falcataria (1773 ppm) (Setyaningsih et al. 2012) and Platanus orientalis (12.7 ppm) (Monfared et al.2013).

The data also showed that BCF value of seedlings exposed to $1.5 \mathrm{mM}$ of $\mathrm{Pb}$ was lower than that exposed to $\mathrm{Pb} 0.5 \mathrm{mM}$. The exposure of 1.5 $\mathrm{mM}$ of $\mathrm{Pb}$ inhibited the plants more and caused more damage than the exposure to $0.5 \mathrm{mM}$ of $\mathrm{Pb}$, which resulted in the reduction of $\mathrm{Pb}$ accumulation from media to the seedling tissues. Another possibility was the leakage or efflux of $\mathrm{Pb}$ and exit back to the media due to damaging effect of $\mathrm{Pb}$. $\mathrm{Pb}$ concentration in seedling roots followed the polimonial pattern of open downwards, while seedling biomass (dry weight) followed the polimonial pattern of open up in response to the increased $\mathrm{Pb}$ concentration (Fig. 3). In other words, exposure to $0.5 \mathrm{mM} \mathrm{Pb}$ caused the highest $\mathrm{Pb}$ concentration in the seedling tissue and resulted in the lowest dry biomass. This suggests that the growth declining of Jabon seedling is highly correlated with the levels of $\mathrm{Pb}$ in the tissue, the higher level of $\mathrm{Pb}$ caused decreasing of growth more indicated by lower dry biomass. Such conditions was also reported by other investigator in $C$. comosum (Wang etal.2011).

The higher TF value of seedling due to $\mathrm{Pb}$ exposure as compared to control suggested that the transfer of $\mathrm{Pb}$ into the shoot of seedling occurred efficiently. TF value of Jabon seedlings was likely to exceed one ( $\mathrm{TF}>1)$ indicating that jabon seedling prefered to keep $\mathrm{Pb}$ in the shoots which could classify jabon as a metal accumulator (Tangahu et al.2011).

$\mathrm{Pb}$ accumulation in Jabon roots was the largest which was almost 3 times of that in the stem $(2.82$ $-10.41 \times 10^{-2} \mathrm{mg} / \mathrm{plant}$ ) and 2 times of that in the leaves $\left(1.73\right.$ - $24.58 \times 10^{-2} \mathrm{mg} /$ plant $)$. Therefore, the sequence of $\mathrm{Pb}$ accumulation in Jabon seedling was the roots $>$ leaves $>$ stem. This phenomenon has also been reported in some other plants such as Kenaf which has been reported to accumulate $\mathrm{Pb}$ up to $97 \%$ of the total bioaccumulation (Mun et al. 2008) and the Indian Mustard which accumulated $\mathrm{Pb}$ more than $95 \%$ (Reisinger et al. 2008). However, the $\mathrm{Pb}$ accumulation capacity of jabon is still lower compared with some other species that have been characterized as $\mathrm{Pb}$ accumulators.. These $\mathrm{Pb}$ accumulators include Brassica campestris $\mathrm{L}$, Brassica carinata A. Br., Brassica juncea (L.) Czern. and Brassica nigra (L.) Koch which could accumulate more than $100 \mathrm{mg} \mathrm{Pb} \mathrm{g}^{-1}$ dry weight (Tangahu et al. 2011).

Although the $\mathrm{Pb}$ concentration in the tissue was relatively small, because this plant produced high biomass with high BCF and TF values, the total $\mathrm{Pb}$ accumulation of Jabon seedling was relatively high. Based on the concept that remediation effectiveness depends on the amount of contaminant accumulated by plant biomass and/or by contaminant level in plant tissues 
(Rodriguez et al. 2005), we conclude that Jabon may have potential function as $\mathrm{Pb}$ remediator.

The efficiency of metal translocation from roots to shoots is one of the key factors to distinguish whether the plant is categorized as metal hyper-accumulator or not. Metal accumulation in the shoot are often limited by the binding of metal cations that is being exchanged in the cell walls of xylem (Kim et al. 2009). However, the hyper-accumulator plant may have the ability to overcome this limitation by forming a negative charge or neutral formation of organicmetal complex. Some aspects such as plant species, properties of medium, the root zone, vegetative uptake and addition of chelating agent are several factors which can affect the uptake mechanism of heavy metals (Rodriguez et al.2005; Tangahu et al. 2011). Formation of metal-organic acid complex also can be an important mechanism to increase the $\mathrm{Pb}$ uptake by plants although free ions of metal are easier to be accessible.

\section{CONCLUSIONS}

Jabon seedlings exhibited tolerant characteristic at least up to $1.5 \mathrm{mM}(450 \mathrm{ppm})$ of $\mathrm{Pb}$, based on some indicators of tolerant index. The $\mathrm{Pb}$ was distributed to all part of the seedlings, with the highest concentration found in the leaves (735.9 ppm). However, because of higher biomass, the highest bioaccumulation was found in the roots $\left(36.55 \times 10^{-2} \mathrm{mg}\right.$ per plant). Jabon seedling can be classified as metal accumulator and may have great potential as remediator in the lead-contaminated areas.

\section{ACKNOWLEDGEMENTS}

The author acknowledges the Government of Republic of Indonesia through the Directorate General of Higher Education for the research fund. Appreciation is also conveyed to the Forest Biotechnology Laboratory, Research Center for Biological Resources and Biotechnology, Bogor Agricultural University (IPB), and Silviculture Laboratory of Nusa Bangsa University, Bogor, Indonesia.

\section{REFERENCES}

Alaribe FO, Agamuthu P. 2015. Assessment of phytoremediation potentials of Lantana camara in $\mathrm{Pb}$ impacted soil with organic waste additives. Ecol Engin 83:513-20. doi: 10.1016/j.ecoleng.2015. 07.001 0925-8574/

Amalia MM, Ernesto FT, Fernando RC, Tania L. 2011. Lead bioaccumulation in Acacia farnesiana and its effect on lipid peroxidation and glutathione production. Plant Soil 339:377-89. doi: 10.1007/s11104-010-0589-6

Capuana M. 2010. Heavy metal and woody plants biotechnologies for phytoremediation. iForest 4:715. doi: 10.3832/ifor0555-004

Ebrahimpour M, Mushrifah I. 2008. Heavy metal concentrations $(\mathrm{Cd}, \mathrm{Cu}$ and $\mathrm{Pb})$ in five aquatic plant species in Tasik Chini, Malaysia. Environ Geol 54(4):689-98.

Flora G, Gupta D, Tiwari A. 2012. Toxicity of lead: A review with recent updates. Interdiscip Toxicol 5:47-58.

Hadi F, Aziz T. 2015. A mini review on lead (Pb) toxicity in plants. J Biol Life Sci 6:91-101.

Henry HF, Burken GJ, Maier MR, Newman AL, Rock S, Schnoor LJ, ... Suk AW. 2013. Phytotechnologies preventing exposures improving public health. Int J Phytoremed 15:889-99. doi: 10.1080/15226514. 2012.760521

Jarvis MD, Leung DWM. 2002. Chelated lead transport in Pinus radiata: An ultrastructural study. Environ Exp Bot 48(1):21-32.

Jiang W, Liu D. 2010. Pb-induced cellular defence system in the root meristematic cells of Allium sativum L. BMC Plant Biol 10:40. doi: 10.1186/1471-2229-10-40

Kim KR, Owens G, Naidu R, Kwon S, Kim KH. 2009. Lead induced organic acid exudation and citrate enhanced $\mathrm{Pb}$ uptake in hydroponic system. Kor J Environ Agric 28(2):146-57.

Kopittke PM, Dart PJ, Menzies NW. 2007. Toxic effects of low concentrations of $\mathrm{Cu}$ on nodulation of cowpea (Vigna unguiculata). Environ Pollut 145:309-15.

Krisnawati H, Maarit K, Markku K. 2011. Anthocephalus cadamba Miq. ecology, silviculture and productivity. Bogor (ID): Center for International Forestry Research.

Monfared SH, Shirvany A, Matinizadeh M, Jalilvand H, Amiri GZ, Fard RM, ... Monemian M. 2013. Comparison of phytoremediation potential and MAI index in Platanus orientalis, Robinia pseudoacacia and Fraxinus rotundifolia. Intl J Agric Crop Sci 6(10):575-82.

Mun HW, Ang LH, Lee DK. 2008. Assessment of Pb uptake, translocation and immobilization in kenaf 
(Hibiscus cannabinus L.) for phytoremediation of sand tailings. J Environ Sci 20:1341-47.

Niu Z, Sun L, Sun T. 2010. Relationships between changes of three organic acid (oxalic acid, citric acid and tartaric acid) and phytoextraction by sunflower (Helanthus annuus L.) in sand cultures contaminated with cadmium and lead. Proceedings: 2010 Dec 2018. Chang Sha $(\mathrm{CN})$ : International Conference on Digital manufacturing and Automation (ICDMA). doi: 10.1109/ICDMA.2010.329

Rascioa N, Navari-Izzo F. 2011. Heavy metal hyperaccumulating plants: How and why do they do it? And what makes them so interesting? Plant Sci 180:169-81.

Reisinger S, Schiavon M, Terry N, Elizabeth AHP. 2008. Heavy metal tolerance and accumulation in Indian mustard (Brassica juncea L.) expressing bacterial $\gamma$ glutamylcsteine synthetase or glutathione synthetase. Int J Phytoremed 10:1-15. doi: 10.1080/ 15226510802100630

Rodriguez L, Lopez-Bellido FJ, Carnicer A, Recreo F, Tallos A, Monteagudo JM. 2005. Mercury recovery from soils by phytoremediation. In: Lichtfouse E, Schwarzbauer J, Rober D, editors. Book of Environmental Chemistry. Berlin (DE): Springer. p. 197-204.
Setyaningsih L, Setiadi Y, Sopandie D, Wilarso BS. 2012. Organic acid characteristics and tolerance of sengon (Paraserianthes falcataria L Nielsen) to lead. JMHT 18(3):177-83. doi: 10.7226/jtfm.18.2.177

Sharma P, Pandey S. 2014. Status of phytoremediation in world scenario. Int J Environ Bioremed Biodegrad 2(4):178-91. doi:10.12691/ijebb-2-4-5

Shu X, Yin LY, Zhang QF, Wang WB. 2011. Effect of Pb toxicity on leaf growth, antioxidant enzyme activities and photosynthesis in cuttings and seedlings of Jatropha curcas L. Environ Sci Pollut Res 9:1-10. doi: 10.1007/s11356-011-0625-y

Sopandie D. 1990. Studies on plant response to salt stress [Dissertation]. Retrieved from University of Okayama.

Tangahu BV, Rozaimah S, Basri H, Idris M, Anuar N, Mukhlisin M. 2011. A review on heavy metals (As, $\mathrm{Pb}$ and $\mathrm{Hg}$ ) uptake by plants through phytoremed. Int J Chem Eng: 31 p. doi:10.1155/2011/939161

Wang Y, Tao J, Dai J. 2011. Lead tolerance and detoxification mechanism of Chlorophytum comosum. AfrJ Biotechnol 10:14516-21.

Xiao W, Hao H, Liu XQ, Liang C, Chao L, Su MY, Hong FH. 2008. Oxidative stress induced by lead in chloroplast of spinach. Biol Trace Elem Res 126:257-68. doi: 10.1007/s12011-008-8195-7 